\title{
Considerations of Sustainable Property Investments in Indonesia
}

\author{
Khaira Amalia Fachrudin', Hilma Tamiami Fachrudin ${ }^{2}$, Elisabet Siahaan¹ \\ ${ }^{1}$ Faculty of Economic and Business, Universitas Sumatera Utara, Jln. TM Hanafiah Kampus USU, Medan, Indonesia \\ ${ }^{2}$ Faculty of Engineering, Universitas Sumatera Utara, Jln. Almamater Kampus USU, Medan, Indonesia \\ Email: khaira@usu.ac.id
}

How to cite this paper: Fachrudin, K.A., Fachrudin, H.T. and Siahaan, E. (2019) Considerations of Sustainable Property Investments in Indonesia. Open Journal of Business and Management, 7, 116-123. https://doi.org/10.4236/ojbm.2019.71008

Received: November 28, 2018 Accepted: December 30, 2018 Published: January 2, 2019

Copyright (c) 2019 by authors and Scientific Research Publishing Inc. This work is licensed under the Creative Commons Attribution International License (CC BY 4.0).

http://creativecommons.org/licenses/by/4.0/ (c) (i) Open Access

\begin{abstract}
Sustainable property is a property that takes into account the sustainability of future generations. This property investment is more expensive than conventional property, but in the long run it can provide a good return. The purpose of this study is to determine the considerations of sustainable property investments. Depth interviews were conducted on national developers who developed sustainable properties and those who did not, consultants, and developer associations. This research type is a qualitative descriptive study. The results of this study show that the investments of sustainable properties are carried out because of self motivations, humanism reasons, and market demands. Civil society like healthy property and willing to pay more because that property will give return enhancement. Bias in investment decision making is not found here because the investment costs are very expensive so the analysis is done very exactly.
\end{abstract}

\section{Keywords}

Sustainable Property, Investments, Behavioral

\section{Introduction}

Investment is a commitment on funds to get profits in the future [1]. Investments can be made through financial assets such as stocks and bonds or real assets such as properties. Investors in making decisions require information in order to obtain optimal benefits and reduce losses [2]. In real estate investments, some investors anticipate trends and changes in property characteristics to create value and profit [3].

Behavioral finance attempts to better understand what seems to be the suboptimal investor decision [4]. Behavioral finance consists of heuristic variables, 
prospects, and markets have a significant effect on financial investor decisions, while herding (the tendency to follow the actions of other investors) has not [5]. This behavior is related to financial assets. For listed property fund manager in South Africa, it has been tested, namely the influence of heuristic and herding on property fund manager investment decisions. The result is the heuristic influence on property investment decisions, but not herding [6].

Sustainable property is a property that is designed with regard to environmental sustainability. The property is emphasizing the sustainability of the place, water efficiency, energy, atmosphere, internal environmental quality, resources and materials. Sustainable property is a property that is in accordance with the concept of sustainable development. Sustainable development is the development that can meet the needs of future generations without sacrificing the needs of future generations [7]. Fachrudin and Fachrudin [8] found that property developers in Medan build properties with sustainable concept, although it is still in a start up that is not yet fully, due to their environmental responsibility and capabilities. Samarietal. [9] explained that there are somebariers in realize sustainable property, among them are investment costs, the expensive sale price and lack of government support.

Cajias and PIazolo [10] said that the concept of sustainability plays an important role for government, society, and especially the real estate sector. Dixon et al. in Wilhelm [11] said that conventional buildings contribute more than $40 \%$ of carbon emissions, $30 \%$ of solid waste, and $20 \%$ of water emissions.

The Governor of DKI Jakarta on March 12, 2018 conducted a raid at the Pan Pacific hotel in Jakarta and found many violations committed by high buildings. Hotel Waste Water Treatment Plant is not complete. The building does not have infiltration wells. Waste water spills out which can contribute to flooding. This is an example of a building that does not apply the sustainability concept.

In Indonesia there are 20 buildings certified by the Green Building Council Indonesia (GBCI). Whereas public companies in the real estate and properties sectors have slightly implemented sustainability concept as many as 15 companies from 45 companies [1].

Robert and Hanneberry [12] had explored decision makings about office investment, Isa et al. [13] have conducted research on investments in green office buildings in Malaysia, and Salzman [14] have explained behaviors in real estate decision making. But no one has examined the reasons of decision making in sustainable property. The uniqueness of this research is examining sustainable property investment decisions that have not been discussed before by many researchers.

This study wants to know the reasons for sustainable investment decisions made by developers in Indonesia, whether it is done because of self-motivation, consideration of risk and return, awareness of the environment, financial abilities, trends, cross-subsidies with conventional property, or other reasons. It is important to know the right approach for the realization of sustainable proper- 
ties in the future.

\section{Literature Review}

\subsection{Sustainable Property Investment}

In investment decisions making, investors need information. Real estate investment decision should apply experience, good judgement, and creativity. It should comparing expected return and degree of risk with investor's strategic, financial, and diversification goals [15].

Risk is a deviation from the expected. Investment in property involves special risks as follows: physical risks such as earthquakes, fires, wear and tear, floods and user damage; risk of liability to third parties because of property damage; tenant risk, if the property is leased, for example risk of damage or any acts by tenants; and economic risk of property such as obsolescence in terms of design or purpose in value over time [16].

Property investment offers return to investors in the form of rent, capital appreciation and cost saving. According to Isa [13], green building investment offers higher return than conventional property.

Investment in sustainable property can increase the value of property and provide financial benefits [17]. Owner of green building will have their savings from the lifecycle building and the cost of its maintenance [8]. In a financial standpoint, the economic dimension is very important; thus, the focus is on long-term economic success of long-term property performance. It is a return.

\subsection{Behavioral Factors}

Consideration of the factors influencing the investors' decision-making process in financial assets cannot ignore the behavioral elements [18]. Behavioral elements consist of heuristics, prospects, market, and herding. Heuristics are attitudes that help make the decision making process easier, for example by using information that is not necessarily right or feels too confident. Prospect theory is a theory related to attitudes that focuses on decision making that affects an investor's valuation system. In short, it can be said that people will have an irrational tendency to be more reluctant to risk profits than losses. Market factors can influence investor decisions such as price changes, market information, past stock trends, stock fundamentals, investor trends, and market reactions. Herding is the tendency of investors to follow the actions of other investors.

\section{Research Method}

This research type is a basic research that is qualitative and aims to enrich the theory. Depth interviews are conducted on respondents. Questions for depth interviews were modified from Isa et al. [13] that is about general opinion on green office building investment, return from green office building investment, and reason for willingness to invest in green office building. The question of behavioral factors influencing investors' decisions making refers to the research of 
Lowies, Hall, and Cloete [6] and Meliza, Sadalia, and Fachrudin [5].

This research was conducted in Jakarta and Medan. Respondents of this study were four company's property managers, i.e. from PT. Duta Sarana Perkasa, Citra Land Bagya City (CLBC), PT. AP, and JW M and CP; three consultants, i.e. consultants as well as the Founder and Chairperson of the Blue Economy Foundation, Reinco Strategies, and PT. Provalindo Nusa; and a chairman of the Indonesian Real Estate Association-North Sumatera Region. Not of all companies have implement green concept on their properties. There are those who implement it as a whole, some apply a part of the concept, some don't apply it at all. The diversity of these objects is important to know the considerations.

The questions in this study consist of two parts. Part A contains questions about the general considerations, return and risk of sustainable property investment. Part B contains questions about behavioral factors.

List of questions for semi-structuredintervieware as follow:

Part A

1) Is the decision to invest in sustainable property a company policy?

2) What are the benefits of sustainable property investment?

3) What are the risks?

4) Is initial cost for construction expensive?

5) Does this application show prestige for your company?

6) Does this application show your concern for the environment?

7) Is sustainability property application a part of your corporate social responsibility?

8) Are your tenants satisfied?

Part B

1) Does the decision of other companies to implement sustainable property make your company want to implement it too?

2) Will your sense of vigilance be more profound when your sustainable property shows a problem compared to pleasure when the property shows profit?

The respondents' answers were summarized and analysed. Data analysis taken in this study were carried out with inductive reasoning, namely from a special premise to the public.

\section{Analysis and Discussion}

There are four companies that were interviewed, i.e. PT. Duta Sarana Perkasa, CLBC, PT. AP, and JW M and CP. PT. Duta Sarana Perkasa has an office building that achieves a platinum certification from the Green Building Council Indonesia because they applied whole of green criteria. CLBC has a big housing complex. They have $48 \%$ green open space and 2 hectares lake for water absorbtion. Company AP has implemented a sustainable concept only in 2 apartments, the application of this concept has not been certified by GBCI. Company JW M and CP does not apply the concept of sustainability. 


\subsection{General Considerations of Sustainable Property Investment}

PT. Duta Sarana Perkasa has a vision that includes, "Providing a good place to work." The founder of this company is also the founder of the Green Building Council Indonesia (GBCI). All green attributes are applied by PT. Duta Sarana Perkasa as a part of their policy. They want to maintain platinum certification they have obtained from GBCI. Their manager is an idealist person.

CLBC has applied it because of its love for the environment. Consultant from Blue Economy Foundation said that the consideration of developing sustainable property investment must protect the environment and not damage it, for example by following the contours of the land and not damaging the trees. For example in the area of Borobudur Temple, a building has been built using the roots and trunks of the tree as its foundation.

Company AP has materialistic consideration that is profit oriented. Their sustainable properties are very popular among some consumers, especially foreign consumers, so the selling prices are higher than conventional properties. JWM and CP does not need to be done, therefore they do not implement it.

The chairman of Indonesian Real Estate Association-North Sumatera Region said that developers will develop sustainable properties if the market is available. It depends on demand. Now, there is not much demand for sustainable properties so developers are reluctant to develop it.

Based on the premise above, it can be concluded that sustainable investment property is generally carried out because of internal motivation, environmental awareness, and profit. This is in line with Fachrudin and Fachrudin [8] which found that sustainable property development is related to environmental responsibility. If the founders or top management do not have motivation within themselves and do not have environmental responsibility, then this investment will be done only for profit reasons, or even they don't do it at all.

\subsection{Benefit of Sustainable Property Investment}

Initial investment cost in sustainable property is higher than conventional investment but operating costs are lower. The advantage of implementing sustainable concepts by PT. Duta Sarana Perkasa and CLBC causes employees feel more comfortable and healthy. CLBC and PT AP also get benefit from higher selling prices.

The CLBC Company invested a lot of initial funds for green open spaces, which is to make lakes for water absorption and also infrastructure. Their initial investment costs 4 times more than conventional housing complexes. Therefore, CLBC's initial profit margin becomes smaller. For CLBC this is not a problem, because operating costs can still be paid. The lake can prevent flooding in the area. Because of these investments, the selling price of land and houses is more expensive than other conventional complexes. Their land price per square meter is Rp. 7 million, while in other similar complexes only Rp. 3 million. Consumers feel satisfied and loyal to the company. They made a repeat purchase and rec- 
ommended CLBC to their friends.

Property consultants said that he had conducted investment analysis for a high-rise building. The building area was planned to be 3000 square meters. The cost of building a high-rise building with sustainable concept was around Rp. 7 million per square meter, while for conventional buildings was Rp. 5.5 million per square meter. However, this building was not built because it was expensive. Internal rate of return (IRR) and net present value (NPV) for sustainable property investment are lower than conventional property. Foreigners like sustainable property, but most Indonesians prefer a cheap one. Like gasoline, someone will definitely choose cheaper gasoline even though there is environmentally friendly gasoline.

So far, there is no incentive to build sustainable property such as lower interest rates for sustainable property funding, but there is a GBCI partner institution that is proposing it. Based on answers from respondents, there is no risk of investing in sustainable property.

\subsection{Behavioral Factors}

Investors who invest in financial assets can be influenced by behavioral factors, such as heuristic, prospects, and market [5]. Investors who invest in conventional property can also be influenced by heuristic factors [6]. Unlike those investments, heuristic behavior is not found in sustainable property investment. All companies in this study have carried out feasibility studies, analysis and considerations before investing. No company has invested in sustainable properties because it mimics the actions of other companies, excessive confidence, or fear. Everything is done based on careful consideration.

\section{Conclusions and Suggestion}

The implication is that awareness of environmental sustainability must be embedded on everyone, especially for the younger generation. If there is awareness, then they will build a house with a better green concept. This is important so that we can provide a good environment for the next generation. Campaigns for sustainable property need to be done, such as training on green building, distributing brochures about awareness of protecting the environment, etc.

Someone must build what he has destroyed. For example someone has built a building in a water catchment area, and then he must make a catchment area in another place. Likewise, when cutting down trees to build buildings, he must plant trees again elsewhere. In building it is not permissible to damage the contours of the soil and trees. With artistic art, buildings can be made with the foundation of existing roots and trunks, such as in the area of Borobudur Temple.

\section{Acknowledgements}

The authors gratefully acknowledge that the present research is supported by Universitas Sumatera Utara in accordance with the contract of TALENTA Un- 
iversitas Sumatera Utara Fiscal Year 2018 No. 2590/UN5.R/PPM/2017 dated March 16, 2018.

\section{Conflicts of Interest}

The authors declare no conflicts of interest regarding the publication of this paper.

\section{References}

[1] Fachrudin, K.A. and Fachrudin, H.T. (2015) The Study of Investment Portfolio Management and Sustainability of Property and Real Estate Companies in Indonesia Stock Exchange. Procedia Social and Behavioral Sciences, 211, 177-183. https://doi.org/10.1016/j.sbspro.2015.11.026

[2] Fachrudin, K.R. and Fachrudin, K.A. (2016) The Influence of Education and Experience toward Investment Decision with Moderated by Financial Literacy. Polish Journal of Management Studies, 14, 51-60. https://doi.org/10.17512/pjms.2016.14.2.05

[3] McMahan (2006) The Handbook of Commercial Real Estate Investing. McGraw-Hill, New York.

[4] Shabgou, M. and Mousavi, A. (2016) Behavioral Finance: Behavioral Factors Influencing Investors' Decisions Making. Advanced Social Humanities and Management, 3, 1-6.

[5] Meliza, J., Sadalia, I. and Fachrudin, K.A. (2012) The Financial Behavior of Investors Using Discriminant Analysis Approach. In: 11 th Ubaya International Annual Symposium on Management, Universitas Surabaya, Surabaya, 902-916.

[6] Lowies, G.A., Hall, J.H. and Cloete, C.E. (2016) Heuristic-Driven Bias in Property Investment Decision-Making in South Africa. Journal of Property Investment \& Finance, 34, 51-67. https://doi.org/10.1108/JPIF-08-2014-0055

[7] Wilhelm, T. (2012) The Incorporation of Sustainable Features in Commercial Property Valuation. Journal of Property Investment \& Finance, 3, 1-13.

https://doi.org/10.1108/jpif.2012.11230daa.002

[8] Jawi, A.I.M., Fachrudin, K.A. and Fachrudin, H.T. (2016) An Investigation of Decision Making Practice upon Sustainable Property Investment in Medan City, Indonesia. The European Proceedings of Social \& Behavioural Sciences BE-ci, 11-22. https://doi.org/10.15405/epsbs.2016.11.02.3

[9] Samari, M., Godrati, N., Esmaeilifar, R., Olfat, P., Shafiei, M.W.M. (2013) The Investigation of the Barriers in Developing Green Building in Malaysia. Modern Applied Science, 7, 1-10. https://doi.org/10.5539/mas.v7n2p1

[10] Cajias, M. and Piazolo, D. (2013) Green Performs Better: Energy Efficiency and Financial Return on Buildings. Journal of Corporate Real Estate, 15, 53-72. https://doi.org/10.1108/JCRE-12-2012-0031

[11] Wilhelm, T. (2012) The Incorporation of Sustainable Features in Commercial Property Valuation. Journal of Property Investment \& Finance, 3, 1-13. https://doi.org/10.1108/jpif.2012.11230daa.002

[12] Roberts, C. and Henneberry, J. (2007) Exploring Office Investment Decision-Making in Different European Contexts. Journal of Property Management \& Finance, 25, 289-305. https://doi.org/10.1108/14635780710746939

[13] Isa, M., Bakar, M.A., Hasim, M.S., Anuar, M.K., Sipan, I. and Nor, M.Z.M. (2017) 
Data Quality Control for Survey Instrument of Office Investors in Rationalising Green Office Building Investment in Kuala Lumpur by the Application of Rasch Analysis. Facilities, 35, 638-657. https://doi.org/10.1108/F-06-2016-0067

[14] Salzman, D. and Zwinkels, R.C.J. (2017) Behavioral Real Estate. Journal of Real Estate Literature, 25, 77-106.

[15] Farragher, E.J. and Savage, A. (2008) An Investigation of Real Estate Investment Decision-Making Practices. Journal of Real Estate Practice and Education, 11, 29-40.

[16] Enever, N., Isaac, D. and Daley, M. (2014) The Valuation of Property Investments. 7th Edition, Routledge. https://doi.org/10.4324/9781315040813

[17] Fachrudin, K.A. and Fachrudin, H.T. (2017) The Effect of Green Home, Green Behavior, and Livability on Financial Incentive in Medan City, Indonesia. IOP Conf. Series. Materials Science and Engineering, 180, 1-6. https://doi.org/10.1088/1757-899X/180/1/012002

[18] Luong, L.P. and Ha, D.T.T. (2011) Behavioral Factors Influencing Individual Investors' Decision-Making and Performance-A Survey at the Ho Chi Minh Stock Exchange. Master Thesis, Umeå University, Umeå. 